\title{
AZ EMPÁTIA, A SZORONGÁS ÉS A SZEMÉLYISÉG SZEREPE A REKLÁMOK ÁLTAL KIVÁLTOTT VÁSÁRLÁSI DÖNTÉSEKBEN
}

\author{
Molnár Edina
}

\section{Összefoglalás}

A marketingkutatás mai tendenciája kevéssé veszi figyelembe a vásárlói döntésben a tartós személyiségvonások, illetve a pillanatnyi érzelmi befolyás szerepét. Jelen kutatásban arra keresem a választ, hogy azon fogyasztók, akik saját bevallásuk szerint a reklámot fontos tényezöként tartják számon a vásárlási döntéseik során, milyen személyiséggel, illetve az érzelmi hozzáállásuk területén milyen beleérzö képességgel rendelkeznek. A kutatásban 965 fó bevonásával, validált személyiség-és empátiateszt kitöltetésével a következö eredményeket kaptam. A reklámot fontos tényezőként itélök esetében a bizonytalanság, a félénkség és a sérülékenység mellett az érzelmi instabilitás jellemzi azokat az egyéneket, akik mások szenvedéseit látva kellemetlenül érzik magukat, szoronganak, vagy magukat esetleg veszélyeztetve is a segiteni akarás vágyát élik meg. Empátiás helyzetben a megemelkedett arousal nagymértékü - esetenként túlságosan nagy - szorongást eredményez, ez azonban nem csak egy pillanatnyi állapot, hanem ezeket az egyéneket általánosan jellemzik a szélsöséges érzelmi reagálások.

Kulcsszavak: empátia, szorongás, személyiség, vásárlási döntés, reklám Jel: D83 


\title{
THE ROLE OF EMPATHY, ANXIETY AND PERSONALITY IN PURCHA- SING DECISIONS CAUSED BY ADVERTISING
}

\begin{abstract}
Today's trend in marketing research takes little into account the role of enduring personality traits and momentary emotional influence in customer decisions. In this research, I am looking for an answer to the fact that consumers who, by their own admission, consider advertising to be an important factor in their purchasing decisions, the personality and the attitude of their emotional attitudes have the capacity to do so. The following results were given by flling out a valid personality and empathy test involving 965 people. Those who consider advertising to be important insecurity, shyness and vulnerability, as well as emotional instability, characterise individuals who feel uncomfortable and have anxious or live on the desire to help endangering themselves. In an empathy situation, elevated arousal causes high levels of anxiety, sometimes too much, but this is not only a momentary state, but these individuals are generally characterized by extreme emotional responses.
\end{abstract}

Keywords: empathy, anxiety, personality, purchasing decision, advertising Jel: D83 


\section{Bevezetés}

\section{Az empátia elméletei}

Nem bizonyultak gyümölcsözőnek azok az elméletek, amelyek az emberi természetet egy általános vonás alapján próbálták meg kategorizálni. Ezek közé tartozik az altruizmus egyszerü elmélete, amely szerint az embereket az a vágy vezérli, hogy jót tegyenek, és segítsék egymást bármiféle viszonzás várása nélkül.

A később kialakult elméletek két nagy csoportja - amely egyébként az egész „pszichológiatudományon" belüli, a nyolcvanas évekig jellemző nagy vitát is tükrözi, nevezetesen és kissé sarkítva az öröklés-környezet vitát - az altruisztikus viselkedést az egyénhez képest belső, illetve külső tényezőkre vezeti vissza. Az előbbi álláspontot képviseli a pszichoanalitikus felfogás. Ezen elmélet szerint altruisztikus viselkedés két úton keletkezhet: egyrészt egészséges azonosulás útján egy altruisztikus figurával, másrészt lehetséges a szorongás és lelkifurdalás leküzdése és átfordítása altruisztikus viselkedésbe. A korai gondozó-gyermek kapcsolat meghatározó az altruizmus két lehetséges mögöttes okának kialakulásában. Az adakozó, segítőkész anyával való azonosulás alakítja ki a felnőttkori segítségnyújtást, míg a segítséghiány és ajándékhiány a gyermekkorban az altruizmus neurotikus formájához vezet.

$\mathrm{Az}$ altruizmus egy lehetséges másik belső okára az etológia ad magyarázatot. Az altruizmusnak túlélési értéke van, amely azonban nemcsak az egyénre korlátozódik, hanem kiterjed a családra - például az „önzetlen” szülői segítség a gyermek felé -, sőt az egész fajra: segítség egy idegennek. Tehát nem az egyén, hanem a gének továbbélése a fontos.

Az altruizmus szituációs felfogását a szociális tanuláselmélet képviseli. A pszichoanalitikus elmélethez hasonlóan a tanuláselméletben is fontos az altruisztikus figura jelenléte, aki azonban itt mint modell szerepel. A segítő viselkedés a jutalmak és büntetések hatásain keresztül alakul ki, és az egyén e hatásokra történő reagálásának függvénye.

A hetvenes-nyolcvanas évek fordulóján kezdett elterjedni az interakciós modell, amely a belső diszpozíciók és a külső tényezők közötti kölcsönhatásokat helyezi előtérbe (ily módon a modell fellépése feloldotta a korábbi öröklés-környezet vitát is). A belső érzelmi állapotok, valamint a hangulat befolyásolja a segítő viselkedést, ugyanakkor a segítés biológiai hajlamát befolyásolja a tanulás és a fejlődés is, sőt maga a segítő viselkedés is fejlődik. Konkrét szituációban tehát a másik szorult helyzete előidéz egy megemelkedett belső állapotot - arousalt -, ami még önmagában nem biztos, hogy segítő viselkedéshez vezet. Szükséges a környezet kiváltó ingere, amit az egyén egy döntési folyamat révén fogad el relevánsnak vagy utasít el. Az érzelmi és a kognitív komponens egy dinamikus, aktív egységet alkot. (A pszichoanalitikus, tanuláselméleti és interakciós modellekről Pervin ad összefoglalást: Pervin 1978/1988, újabban és a gazdasági vonatkozásokat is szem előtt tartva Karajz, 2018.) 


\section{Az empátia ontogenetikus kialakulása és fejlödése: „nyugat és kelet” két elmélete az empátiafejlödésröl}

A következőkben Martin Hoffman empátiafejlődés-elméletét (Hoffman, 2000) és Takie Sugiyama Lebra elgondolásait a japán szocializációról (Lebra, 1994) vesszük szemügyre.

Mindkét szerző a korai anya-gyerek szimbiózisban gyökerezteti az altruisztikus viselkedést, feltűnő különbség azonban, hogy az előbbi a gyermek, az utóbbi az anya oldaláról közelíti meg az empátiafejlődést, ami a kultúrák közötti alapvető különbséget is tükrözi.

Hoffman elméletében a gyermek fokozatos én-másik elkülönítésén alapul, és ezzel párhuzamosan halad az empátiafejlődés. Az első életévben a másik szenvedése láttán megjelenik a saját komfortérzésre való törekvés. A második évben - az én-nem én-differenciáció kezdetén - a másik és a saját megnyugtatása lép előre. A kognitív vonal mellett a gyermek az érzelmeiben is kettősséget él át, amelyet a saját distressz és csökkentése, valamint a másik distressze iránti aggodalom érzete okoz. Az altruista viselkedés kialakulásának előfeltétele, hogy a gyermek érezze, hogy a saját és a másik szenvedésének enyhítésére irányuló vágya összefügg. Ez a szakasz átmenet a kezdeti „kvázi egoisztikus distresszválasz” és a valódi együttérzés között, amelynek alapja a másikkal való foglalkozás megjelenése a második év után.

A japán kultúrában az omoiyari (az empátia megfelelője) a morális értékek hierarchiájának csúcsán áll. A szülők tudatosan igyekeznek elérni, hogy gyermekükben meggyökeresedjen az omoiyari érzése. Az anya kifejezetten az empátia megtestesítője. Önzetlenség és önfeláldozó nélkülözés kell, hogy jellemezze. A gyermeknevelésben a gyermeket az empátia utánzására és viszontválaszra bátorítja verbálisan. Azt gyakoroltatja be a gyermekével, hogy úgy érezzen, ahogy ő. Ha ez sikeres, a gyermek érzékennyé válik arra, hogy átérezze anyja érzéseit, fájdalmait, kívánságait. Ekkor az anya már irányítani tudja. Így tehát a gyermek korábban kontrollálatlan egocentrikus viselkedése - ami egyébként elfogadott és megengedett, mint korspecifikus tulajdonság - kontroll alá kerül az anyai empátiává változás útján. A gyermek abbahagyja azokat a viselkedésformákat, amelyek bántják anyja érzéseit, vagy amelyek miatt szégyenkezhetnek a szülei.

Az empátia elsajátítása fejlesztően hat a gyermek szociális érzékenységére anyja iránt és rajta keresztül mások iránt. Ez később felnőttkorban is megmutatkozik abban, hogy kötelességének érzi annak elkerülését, hogy mást zavarjon. A gyermek tehát az empátiás nevelésen, az identitásfejlődés elkerülhetetlen alapján keresztül válik autonóm lénnyé (Lebra, 1994).

Mindkét elmélet az anya-gyerek duálunióból indul ki, és nagy súlyt fektet az empátiás érzések fejlődésének szerepére a teljes emberré válás útján. 


\section{Empátia és egészség}

Ahhoz, hogy a világban ne csak egyszerü „információfeldolgozó szakemberként” éljünk, szükségünk van a spontaneitásra, a spontán beleélés képességére (Buda, 2012).

Kohut szerint (Kohut, 1985) az empátia segítségével a másik ember egy intuitív benyomást tesz ránk, amely folyamatában az arcfelismerés hirtelen, nem szándékos, intuitív jellegéhez hasonlítható. Az empátiás ráhangolódás és az arcfelismerés közös jellege Kohut szerint a korai anya-gyermek kapcsolatban gyökerezik, és innen indul fejlődésnek. A gyermek első élménye az anya arca, amely a beleélést, tükrözést és elismerést fejezi ki, így biztosítva az egészséges személyiségfejlődést. A későbbiekben erre az ősi empátiás létezésre épül rá az információk elemzése, a kognitív hozzáállás. Kohut az előbbit elsődleges, az utóbbit másodlagos gondolkodási folyamatnak nevezi. Az egyén életében mindkettő megvan, a kettő egyszerre működik, nem zárják ki egymást.

Kohut személyiségfejlődési elméletében az anya mint tükröző éntárgy segíti a gyermek grandiózus selfillúziójának átformálódását. Mahler elméletében (Mahler, Pine, Bergman, 1987) ez a szakasz az omnipotens, pajzzsal védett anya-gyermek rendszerének felel meg, amely fokozatosan bomlik fel, és a gyermek a kikelés folyamatának segítségével a szeparáció és individuáció során válik autonóm, egészséges lénnyé.

A kohuti elméletben a grandiozitást az idealizáció váltja fel. A gyermek számára a szülő - főleg az apa - ideállá válik, ez segíti elő a gyermek felettes énjének kiépülését. Az ideálhoz való hasonlóság motivációja az ambíció. Az ideál az egyénhez képest külső, az ambíció belső diszpozíció. Ezekből és a nárcisztikus ellátás igényéből (amely az anya tükröző viselkedése) fejlődik ki a transzformált nárcizmus, amely Kohut szerint öt összetevőből áll. A kreativitás, az empátia, a végesség elfogadása, a humorérzék és a bölcsesség komplexuma az önérdek meghaladása érdekében fejlődik ki. Az egészséges személyiség tehát magában hordozza a gyermeki empátiát, az ideálokat - mint pl. a munka tárgya -, elfogadja az egyénen túli, transzcendentális létezést, a belső megnyugvás manifesztációját és az értékek felsőbbrendűségének elfogadását a halálhoz képest.

Az empátia képessége feltétlenül szükséges a mindennapi élethez: Kohut szerint az egyszerű mozgásokat sem tudnánk értelmezni empátia - és intrapszichikus megfelelője, az introspekció - nélkül. Elengedhetetlen a gyógyításban, a tanításban, sőt a modern társadalmak erre építenek a reklámok vagy filmek bemutatásakor.

A XIX-XX. század társadalmi berendezkedései az egyének elidegenedését eredményezik. Minden automatizálódik és felgyorsul, így egyre kevesebb idő és energia marad az emberi kapcsolatok ápolására. A mindennapi rohanásokban az empátia az, ami összekötheti az embereket és a kapcsolatok összetartása révén biztonságot ad (Davis, 2018). 
Az empátia kísérleti megközelítése: egy folyamat- és egy multidimenzionális modell A más személy állapota által kiváltott és az azzal kongruens érzelmi állapotot nevezhetjük empátiának. A Batson és Coke e meghatározásában szereplő állapot tulajdonképpen a megnövekedett arousalszint. Ezen alapszik a két szerző modellje (Batson és Coke, 1983/1988), amely a segítségnyújtás két szakaszát különíti el. Az első szakaszban a kognitív szempontátvétel növeli az empátiás emocionális reakciót. A szerzők által idézett kísérletben a megfigyelők, akiket a célszemély szempontjának átvételére instruáltak, nagyobb fiziológiai arousalt produkáltak, mint azok, akiknek a célszemély mozgását kellett figyelniük, sőt az előbbi megfigyelők a megemelkedett arousalt a célszemély észlelt állapotával kongruens módon címkézték.

A modell második szakaszában az empátiás emóció növeli a segítségnyújtás motivációját. Az ehhez kapcsolódó kísérletben a kísérletvezetők két feltételt variáltak. A kísérleti személyek egy lány szomorú sorsáról hallgattak rádióadást. Az egyik csoport feladata az volt, hogy próbálja beleélni magát a lány helyzetébe, a másik csoportnak az adás technikáját kellett megfigyelnie. A másik variált feltételben nyugtató, ill. izgatószernek nevezett placebót kaptak a kísérleti személyek. Az elvárásnak megfelelően azok a kísérleti személyek címkézték hasonlóan a lány érzelmeihez a megemelkedett arousalszintjüket és segítettek rajta, akiket a beleélésre instruáltak, és úgy tudták, hogy nyugtatót kaptak.

A másik ember szenvedésének látványa tehát fiziológiai reakciót hoz létre, amelyet az egyén a megfigyelt személy érzéseivel kongruensen címkéz, ami az áldozat szenvedésének csökkentésére irányuló motivációt eredményez.

Batson és munkatársai egy korábbi vizsgálatukban (Batson, Duncan, Ackerman, Buckley, Birch, 1981) megvizsgálták azt a feltevést, hogy a segítségnyújtás egoisztikusan motivált-e, vagy van-e ténylegesen altruisztikus segítés is. A hoffmani empátiafejlődés-elmélet szerint mindkettőnek van alapja a korai személyiségfejlődésben. A saját distressz átélése - vagyis a megfigyelő megemelkedett arousalja - eredményezheti azt, hogy a megfigyelő végső soron ezt próbálja meg csökkenteni, a segítést ehhez csak eszközül felhasználva.

Egoista motiváció esetében tehát cél a szenvedő látványa által okozott személyes distressz csökkentése segítségnyújtással vagy meneküléssel. Az előbbit akkor választja a megfigyelő, ha az utóbbi még negatívabb érzelmeket ébresztene benne, mint a distressz, például bűntudatot vagy szégyent. Ebből következik, ha növeljük a menekülés negatív következményeinek intenzitását vagy számát, akkor a segíteni akarás foka is emelkedni fog. Ha viszont csökkentjük a következményeket, akkor a segíteni akarás foka is csökken. Ezzel szemben az altruisztikus motiváció független a menekülés következményeitől, mert a megfigyelő ebben az esetben a másik szenvedését akarja csökkenteni.

Batson és mtsai két kísérletet végeztek ehhez kapcsolódóan (Batson és mtsai, 1981). Az első kísérletben egy lányt kellett nézniük a kísérleti személyeknek, aki 
áramütéseket kapott. Két feltételt variáltak a kísérletvezetők: a megfigyelt személy és a kísérleti személyek hasonlósága vs. különbözősége és könnyü vs. nehéz menekülési feltétel. Abban az esetben, amikor a kísérleti személy úgy tudta, hogy a megfigyelt személy hasonló hozzá, akkor ez altruisztikus segítségnyújtást eredményezett, a másik feltétel variálása nem volt hatással a kísérleti személyre. A másik esetben azonban, amikor a kísérleti személy és a megfigyelt személy különböztek és ez az egoisztikus motivációt hívta elő, a megfigyelt személy nagyobb szenvedésének látása (több áramütést kapott - nehéz menekülési feltétel) segítségnyújtást eredményezett.

A másik kísérletben a hasonlósági feltétel helyett a placebónak tulajdonított empátiás aggodalom vagy személyes distresszfeltételt variálták. Az eredmények alátámasztották az első kísérlet eredményeit: a distresszfeltételben, ahol a motiváció egoisztikus volt, a segítségnyújtás foka alacsonyabb volt a könnyü, mint a nehéz menekülési helyzetben.

Az egoisztikus és altruisztikus motivációjú segítségnyújtásból kinőve és szintén kapcsolódva a hoffmani empátiafejlődéshez, az empátia újabb kutatásai egy multidimenzionális megközelítést eredményeztek (Davis, 1983).

A globális empátiát négy aspektusával jellemezhetjük:

- perspektívafelvétel, amely a másik ember nézőpontjának átvételét jelenti pl. vitában,

- fantázia, amely során az egyén film- és regényhősök helyzetébe képzeli magát,

- empátiás aggodalom, amely a másik iránti együttérzést fejezi ki, valamint

- $\quad$ személyes distressz, amely feszült interperszonális helyzetekben az egyén kellemetlenség-, szorongásérzetét ragadja meg.

Davis kidolgozta az interperszonális reaktivitási indexet (IRI), amelyben a fenti négy összetevő egy-egy alskálát alkot. Vizsgálatában a négy IRI-skála és öt ehhez kapcsolódó konstruktum viszonyát elemzi: szociális kompetencia, önértékelés, emocionalitás, mások iránti érzékenység és - csupán tájékozódó jelleggel - intelligencia. Az előbbiek elméleti vagy logikai úton kapcsolódnak az IRI-skálákhoz. A perspektívafelvétel pozitívan korrelált a szociális kompetenciával, az önértékeléssel, mások megértésével és negatívan az önközpontú érzékenységgel (ami azt jelenti, hogy az egyén milyen benyomást kelt másokban). A fantáziamutató pozitívan korrelált a verbális intelligenciával és az emocionális reaktivitással, valamint a férfiaknál az érzékenységgel. Az empátiás aggodalom pozitívan korrelált mások megértésével és az emocionalitással. A distressz pozitívan korrelált a szégyenlősséggel, a szociális szorongással, az emocionális sebezhetőséggel és a mások iránti önközpontú érzékenységgel. 


\section{Vásárlási döntések és empátia}

A vásárlási döntést befolyásoló egyik tényező a vásárló személyisége. Elterjedt a vásárlási döntések kommunikációs folyamatként való leírása és elemzése (Pólya, 2018), illetve egyéb, a családot előtérbe állító modellek (pl. Horváthné et al., 2012, Földi, 2011) is jelen vannak, vagy a személyiség egy aspektusát figyelembe vevő operacionalizált kutatások, pl. Agárdi, 2019 vagy Korpás Szabó, 2019. Kevés szó esik azonban a vásárlói személyiségről, vagy azt általában egyoldalúan értelmezik, kevés figyelmet fordítva a személyiség mélyebb pszichológiai elemzésére.

A marketingkutatásban jellemzően két területen jelenik meg az empátia vizsgálata. Az egyik terület a személyes eladás, ahol a szolgáltatást vagy árut igénybe vevők, illetve kínálók empatikus hozzáállásának hatását vizsgálják az eladási folyamatra (Delpechitre, Rutherford, Comer, 2019; Bahadur, Khan, Ali, Usman, 2019; Zerbini, Vergura, Luceri, 2019; Umasuthan, Park, Ryu, 2017).

A másik terület az eleve empátiára építő jótékonysági hirdetések területe (Weiss, Cohen, 2019; Bartsch, Kloss, 2018; Keskin, Akgun, Ayar, Etlioglu, 2017).

Saját vizsgálatomat Kohut azon meglátása inspirálta, hogy a mindennapi élet elengedhetetlen feltétele az empátia, amelyet a reklámok is kihasználnak. A vizsgálatomhoz három adalék szolgál alapul. Egyrészt a segítő viselkedés folyamatmodelljéből az empátiás gerjedelem (Pervin, 1978/1988) és az a megállapítás, hogy a magasabb arousal nagyobb mérvű segítségnyújtáshoz vezet (Batson és Coke, 1983/1988). Másrészt ehhez kapcsolódóan Hebb ismert görbéje (Hebb, 1975) az ingerek viselkedést irányító hatékonyságának és az arousalszintnek az összefüggéséről: az arousalszint további emelkedése az optimális szint után már érzelmi zavart okoz. Harmadrészt pedig Davis eredményei a személyes distressz korrelációival kapcsolatban (Davis, 1983).

Kérdésfeltevésem az, hogy a reklámot saját magukra nézve fontos vásárlási tényezőként tekintő egyének személyes distressze - azaz a másik ember szenvedésének átélése közben keletkezett megemelkedett arousalja - együttjár-e a mindennapi élethelyzetekben fellépő emocionális labilitással. Vagy másképpp: a reklámot fontosnak tartó egyének esetében a szituáció hatásának tűnő, pillanatnyi magas arousal okozza-e a személyes distressz vagy az empátiás aggodalom fellépését, vagy tekinthetjük ezt egy stabil személyiségvonásnak, amely általában jellemző reagálásmódot jelentene az empátiát igénylő helyzetekben.

\section{Anyag és módszer}

\section{Vizsgálati személyek}

A kutatás első szakaszában 1864 felnőttel vettem fel kérdőívet. A kérdőív eredményei alapján a vizsgálati személyeket két csoportra osztottam, az első csoport úgy nyilatkozott, hogy nem érzi döntő tényezőnek, a másik csoport viszont kiemelte befolyásoló 
tényezőként a reklámokat a vásárlási döntései során. A továbbiakban ez utóbbi csoport vizsgálatának folyamatát és eredményeit mutatom be. A csoport elemszáma 965 fó.

\section{Eszközök}

Az empátia és a szorongás mérésére Davis IRI-skáláját alkalmaztam (Davis, 1983). A vizsgálati személyeknek 28 állításról kellett eldönteniük, hogy mennyire jellemzi őket, és ezt egy ötfokú skálán jelezni $(0=$ nem jellemző, 4 = nagyon jellemző). A kérdőív egyaránt tartalmaz egyenes és fordított állításokat. Az állításokra adandó pontszám a személy által adott számokkal egyenlő. Az alskálákat külön kell összegezni. Minden alskála hét állítást tartalmaz, így 0-28 pont adható.

A személyiséget a Big Five személyiségteszttel mértem (Caprara, Barbaranelli és Borgogni, 1993; magyar változat Rózsa, 1995). A 132 tételes kérdőívre az egyetértés öt fokozatával kellett válaszolni, a pontozás megegyezik az előbbiekben leírtakkal. Az öt személyiségfaktort a szerzők két-két alskálára bontották, valamint hozzátettek egy szociális kívánatosságot mérő skálát is, amely a vizsgálati személy azon hajlandóságát mutatja, hogy mennyire torzítja a magáról kialakított képet a másoknak való megfelelni vágyás szükséglete. Minden alskála 12 tételből áll.

\section{Eljárás}

A két kérdőívet egy alkalommal vettem fel az egyes vizsgálati személyekkel, először a Big Five-ot, utána az IRI-t. Mindkét kérdőíven szerepel a kitöltés instrukciója, a vizsgálati személy egyedül tölti ki a válaszlapokat.

\section{Eredmények}

A vizsgálati személyek egyes alskálákon elért átlageredményei és szórásai a következők:

\begin{tabular}{|l|l|l|l|}
\cline { 3 - 4 } \multicolumn{2}{c|}{} & \multicolumn{1}{c|}{ Átlag } & \multicolumn{1}{c|}{ Szórás } \\
\hline \multirow{5}{*}{ IRI } & Fantáziaskála & $\mathbf{1 4 , 5}$ & $\mathbf{6 , 7 4 7 3 1 9}$ \\
\cline { 2 - 4 } & Perspektívafelvétel & $\mathbf{1 7 , 0 5}$ & $\mathbf{5 , 1 3 4 7 6 3}$ \\
\cline { 2 - 4 } & Empátiás aggodalom & $\mathbf{1 8 , 0 5}$ & $\mathbf{6 , 3 2 0 1 8 5}$ \\
\cline { 2 - 4 } & Személyes distressz & $\mathbf{1 7 , 4 5}$ & $\mathbf{6 , 2 7 0 0 2 1}$ \\
\hline \multirow{3}{*}{ Big Five } & Dinamizmus & 36,6 & 5,968338 \\
\cline { 2 - 4 } Dinamizmus + Dominancia & Dominancia & 36 & 5,866946 \\
\cline { 2 - 4 } & Energia & $\mathbf{7 2 , 6}$ & $\mathbf{1 0 , 2 3 6 1 6}$ \\
\hline
\end{tabular}




\begin{tabular}{|l|l|l|l|}
\hline \multirow{4}{*}{$\begin{array}{l}\text { Együttmüködés + } \\
\text { Udvariasság }\end{array}$} & Együttmúködés & 44,3 & 4,835178 \\
\cline { 2 - 4 } & Udvariasság & 40,4 & 4,998947 \\
\cline { 2 - 4 } & Barátságosság & $\mathbf{8 4 , 7}$ & $\mathbf{8 , 6 6 3 9}$ \\
\hline \multirow{5}{*}{ Pontosság + Kitartás } & Pontosság & 39,4 & 8,133103 \\
\cline { 2 - 4 } & Kitartás & 40,3 & 7,540068 \\
\cline { 2 - 4 } & Lelkiismeretesség & $\mathbf{7 9 , 7}$ & $\mathbf{1 3 , 1 3 5 3 3}$ \\
\hline \multirow{4}{*}{$\begin{array}{l}\text { Emocionális + Impulzus } \\
\text { kontroll. }\end{array}$} & $\begin{array}{l}\text { Emocionális } \\
\text { kontrollálatlanság }\end{array}$ & 44,15 & 11,14628 \\
\cline { 2 - 4 } & $\begin{array}{l}\text { Impulzus } \\
\text { kontrollálatlansága }\end{array}$ & 38,6 & 9,697531 \\
\cline { 2 - 4 } & Neuroticitás & $\mathbf{8 2 , 7 5}$ & $\mathbf{1 8 , 8 2 5 7 2}$ \\
\hline \multirow{5}{*}{ Kultúrára + Tapasztalatokra } & Nyitottság a kultúrára & 41 & $\mathbf{6 , 9 8 8 7 1 3}$ \\
\cline { 2 - 4 } & Nyitottság a tapasztalatokra & 39,95 & $\mathbf{6 , 6 2 1 1 3 8}$ \\
\cline { 2 - 4 } & Nyitottság & $\mathbf{8 0 , 9 5}$ & $\mathbf{1 2 , 3 2 6 5 9}$ \\
\hline
\end{tabular}

1. táblázat A vizsgálati személyek alskálánkénti átlagai és szórásai

Saját forrás, saját szerkesztés

Az IRI-kérdőív alskáláit szintén korreláltattam a Big Five alskáláival. A korrelációk a következőképpen alakultak az IRI és a felosztott Big Five-alskálák között:

\begin{tabular}{|l|l|l|l|l|}
\cline { 2 - 5 } \multicolumn{1}{c|}{} & Fantáziaskála & $\begin{array}{c}\text { Perspektíva- } \\
\text { felvétel }\end{array}$ & \multicolumn{1}{|c|}{$\begin{array}{c}\text { Empátiás } \\
\text { aggodalom }\end{array}$} & \multicolumn{1}{|c|}{$\begin{array}{c}\text { Személyes } \\
\text { distressz }\end{array}$} \\
\hline Dinamizmus & 0,145072 & $-0,01477$ & 0,275429 & 0,017721 \\
\hline Dominancia & $-0,01197$ & $-0,02446$ & $-0,18878$ & $-0,20031$ \\
\hline Együttmüködés & 0,072596 & $-0,08543$ & 0,311216 & $-0,1401$ \\
\hline Udvariasság & $0,454077^{*}$ & 0,14066 & $0,450781^{*}$ & 0,146761 \\
\hline Pontosság & $-0,10838$ & $-0,1719$ & 0,057953 & $-0,27$ \\
\hline Kitartás & 0,073451 & $-0,10916$ & $-0,02463$ & $-0,15441$ \\
\hline Emocionális ktr. & 0,337662 & 0,096419 & $0,612521 * *$ & $0,645136 * *$ \\
\hline Impulzus ktr. & 0,127894 & 0,113519 & 0,375607 & 0,338103 \\
\hline Nyitottság a kult. & 0,158492 & $-0,3168$ & 0,14418 & $-0,18857$ \\
\hline Nyit. a tapasztal. & $-0,11486$ & $-0,19808$ & $-0,05905$ & $-0,25425$ \\
\hline
\end{tabular}

$\left(+\mathrm{p}<0,1,{ }^{*} \mathrm{p}<0,05,{ }^{* *} \mathrm{p}<0,01\right)$

2. táblázat Alskálák közötti korrelációk

Saját forrás, saját szerkesztés 
Az IRI-alskálák és az öt személyiségdimenzió - valamint a szociális kívánatosság - korrelációi:

\begin{tabular}{|l|l|l|l|l|}
\cline { 2 - 5 } \multicolumn{1}{c|}{} & Fantáziaskála & $\begin{array}{c}\text { Perspektíva- } \\
\text { felvétel }\end{array}$ & \multicolumn{1}{|c|}{$\begin{array}{c}\text { Empátiás } \\
\text { aggodalom }\end{array}$} & $\begin{array}{c}\text { Személyes } \\
\text { distressz }\end{array}$ \\
\hline Energia & 0,077728 & $-0,02263$ & 0,052392 & $-0,10447$ \\
\hline Barátságosság & 0,302511 & 0,033481 & $0,433779+$ & 0,006491 \\
\hline Lellkiismeretesség & $-0,02494$ & $-0,1691$ & 0,021746 & $-0,25581$ \\
\hline Neuroticitás & 0,265803 & 0,115564 & $0,556143 *$ & $0,556134^{*}$ \\
\hline Nyitottság & 0,02816 & $-0,28601$ & 0,050026 & $-0,24348$ \\
\hline Szociális kívánatosság & $-0,12754$ & $-0,44208+$ & $-0,32972$ & $-0,41137+$ \\
\hline
\end{tabular}

\section{3. táblázat Személyiségdimenziók és az empatikus jellemző közötti korrelációk Saját forrás, saját szerkesztés}

Tájékozódásképpen megnéztem a két kérdőíven belül is az alskálák korrelációit. Az IRI-n belül a fantáziaskála és az empátiás aggodalom, ill. a fantáziaskála és a személyes distressz között mutatható ki szignifikáns korreláció. A Big Five-on belül a legtöbb szignifikáns és nagymértékű együttjárást kifejező korrelációja az energiának - ezen belül a dinamizmusnak -, a lelkiismeretességnek, a nyitottságnak - ezen belül a nyitottságnak a kultúrára - és a szociális kívánatosság alskáláknak volt.

\section{Következtetések}

A reklámot fontos tényezőként ítélők fenti táblázataiból kitűnik, hogy szignifikáns pozitív korreláció áll fenn a neuroticitás - és ezen belül az emocionális kontrollálatanság - és az empátiás aggodalom, ill. a személyes distressz között. Ez azt jelenti, hogy az empátiát igénylő helyzetekben az altruisztikus vagy egoisztikus empátia alkalmazása attól függ - azzal jár együtt -, hogy a megfigyelő személy neuroticitása mekkora, azaz általában az érzelmet kiváltó helyzetekben milyen mértékben engedi át magát az érzelmeinek anélkül, hogy kontrollálná azokat.

Szignifikáns pozitív a korreláció az udvariasság és a fantáziaskála, ill. empátiás aggodalom és tendenciaszerű a kapcsolat a barátságosság és az empátiás aggodalom között. Azaz az udvarias, barátságos személyek empátiás helyzetekben magas fokú altruisztikus empátiát élnek át.

A perspektíva felvétel és a személyes distressz negatívan korrelál a szociális kívánatossággal. Az a megfigyelő, aki kevésbé képes beleélni magát a vitapartnerének 
a nézőpontjába, és kevéssé szorong a másik szenvedése láttán, a társadalmi elvárásokat inkább figyelembe veszi. A társadalom által elvárt a figyelem és odafordulás a szorult helyzetben lévő másik felé, ezért ennek azt kellene maga után vonnia, hogy a szociális kívánatosság skálája és a perspektívafelvétel között a korreláció pozitív. Az is elképzelhető azonban, hogy aki hazudik, éppen azt hazudja, hogy nem szorong, azért, hogy magát is megvédje. Elképzelhető ilyen torzítás az énvédelem érdekében. A kapott eredmény furcsa, a kapcsolat azonban csak tendenciaszerü. Újabb vizsgálat elvégzése esetleg más eredményt adna.

Összefoglalva: a személyiségfaktorokat és az IRI skáláit tekintve tendenciát mutat negatív irányban a szociális kívánatosság a perspektívafelvétellel és a személyes distresszel, ugyancsak tendenciaszerű a kapcsolat a barátságosság és az empátiás aggodalom között. Elvárásommal összhangban szignifikáns pozitív kapcsolat mutatható ki a neuroticitás és az empátiás aggodalom, ill. személyes distressz között. Az értelmezésnél vigyáznunk kell, mert könnyen eshetünk abba a hibába, hogy a neuroticitás magas fokát oknak tekintjük az altruisztikus vagy egoisztikus empatizálásban. Az eredmények csupán azt mutatják, hogy a két empátiás megközelítés együtt jár az érzelmi instabilitással.

A reklámot fontos tényezőként ítélők esetében a bizonytalanság, a félénkség és a sérülékenység mellett az érzelmi instabilitás jellemzi azokat az egyéneket, akik mások szenvedéseit látva kellemetlenül érzik magukat, szoronganak vagy magukat esetleg veszélyeztetve is a segíteni akarás vágyát élik meg. Empátiás helyzetben a megemelkedett arousal nagymértékű - esetenként túlságosan nagy - szorongást eredményez, ez azonban nem csak egy pillanatnyi állapot, hanem ezeket az egyéneket általánosan jellemzik a szélsőséges érzelmi reagálások.

\section{Hivatkozott források}

[1.] Agárdi I. (2019): A tapintás iránti preferencia mediáló hatása a fogyasztó neme, a termék típusa és a csatornaválasztás kapcsolatában. Vezetéstudomány - Budapest Management Review, 50 (1). pp. 70-79.

[2.] Bahadur, W., Khan, A., Ali, A., Usman, M. (2019): Investigating the Effect of Employee Empathy on Service Loyalty: The Mediating Role of Trust in and Satisfaction with a Service Employee. Journal of Relationship Marketing. 10.1080/15332667.2019.1688598

[3.] Bartsch, A., Kloss, A. (2019): Personalized charity advertising: Can personalized prosocial messages promote empathy, attitude change, and helping intentions toward stigmatized social groups? International Journal of Advertising. pp. 345-363. 
[4.] Batson, D. C., Coke, J. S. (1983): A segítő viselkedés empátiás motivációja. In: Barkóczi I., Séra L. (szerk.): Az emberi motiváció I. Tankönyvkiadó, Budapest, 1988. pp. 299-317.

[5.] Batson, D. C., Duncan, B. D., Ackerman, P., Buckley, T., Birch, K. (1981): Is Empathic Emotion a Source of Altruistic Motivation? Journal of Personality and Social Psychology, 40. pp. 290-302.

[6.] Buda Béla (2012): Empátia - A beleélés lélektana. L’Harmattan Kiadó, Budapest.

[7.] Caprara, G. V., Barbaranelli, C., Borgogni, L., Perugini, M. (1993): The Big Five Questionnaire: A new questionnaire to access the five factor model. Personality and Individual Differences, 15. pp. 281-288. Magyar változat: Rózsa S. 1995. ELTE.

[8.] Davis, M. H. (1983): Measuring individual differences in empathy: Evidence for a multidimensional approach. Journal of Personality and Social Psychology, 44. pp. 113-126.

[9.] Davis, M. H. (2018): Empathy: A social psychological approach. Routledge, New York.

[10.] Delpechitre, D., Rutherford, B. N., Comer L. B. (2019): The importance of customer's perception of salesperson's empathy in selling. Journal of Business \& Industrial Marketing Vol. 34 No. 2, pp. 374-388.

[11.] Földi K. (2011): A nők élelmiszer-vásárlási magatartása. Economica (Szolnok) $4: 10$ pp. 73-81.

[12.] Hebb, D. O. (1975): A pszichológia alapkérdései. Gondolat, Budapest, pp. 228-233.

[13.] Hoffman, M. L. (2000): Empathy and Moral Development: Implications for Caring and Justice. Cambridge: Cambridge University Press.

[14.] Horváthné Kökény A., Bálint Á., Kulcsár P., Oravecz G. (2012): A háztartások pénzügyi döntései: gondoskodjunk a jövőnkről. Szolnoki Tudományos Közlemények 16 pp. 20-27.

[15.] Karajz S. (2018): Az altruista viselkedés modellezési lehetőségei. Északmagyarországi Stratégiai Füzetek, Faculty of Economics, University of Miskolc, Vol. 15(1), pp. 82-91.

[16.] Keskin, H., Akgün, A, Ayar, H., Etlioglu, T. (2017): Persuasive messages and emotional responses in social media marketing. Journal of Management, Marketing and Logistics. 4. pp. 202-208. 
[17.] Kohut, H. (1985): Self Psychology and the Humanities. Ed. by Charles B. Strozier. W. W. Norton \& Co., New York \& London.

[18.] Korpás, Z., Szabó, B. (2019): Az online reklámok közvetlen hatásának vizsgálata a vásárlási döntésekre. Marketing \& Menedzsment 53(2), pp. 31-44.

[19.] Lebra, T. S. (1994): Mother and child in Japanese socialisation: Japan - U. S. comparison. In: Greenfield, T. M., Cocking, R. R. (Eds.): Cross Cultural roots of minority child development. Lawrence Erlbaum associates. pp. 262-263.

[20.] Mahler, M. S., Pine, F., Bergman, A. (1987): The Psychological Birth of the Human Infant. Maresfield Library, London.

[21.] Pervin, L. A. (1978): Altruizmus. Miért segítenek az emberek és miért nem? In: Barkóczi I., Séra L. (szerk.): Az emberi motiváció I. Tankönyvkiadó, Budapest, 1988. pp. 271-298.

[22.] Pólya É. (2018): A családon belüli vásárlási-döntési folyamatok komplex modellje. Gradus 5: 2 pp. 117-122.

[23.] Investigating the Effect of Employee Empathy on Service Loyalty: The Mediating Role of Trust in

[24.] and Satisfaction with a Service Employee, Journal of Relationship Marketin

[25.] Investigating the Effect of Employee Empathy on Service Loyalty: The Mediating Role of Trust in

[26.] and Satisfaction with a Service Employee, Journal of Relationship Marketing

[27.] Umasuthan, H., Park, O. and Ryu, J. (2017): „Influence of empathy on hotel guests' emotional service experience", Journal of Services Marketing, Vol. 31 No. 6, pp. 618-635.

[28.] Weiss, J. K., Cohen, E. L. (2019): Clicking for change: the role of empathy and negative affect on engagement with a charitable social media campaign. Behaviour \& Information Technology, 38: 12, pp. 1185-1193.

[29.] Zerbini, C., Vergura, D. and Luceri, B. (2019): How fair-trade claims and emotional empathy affect the consumer's propensity to buy fair chocolate? British Food Journal, Vol. 121 No. 7, pp. 1605-1613. 


\section{Szerző}

\section{Molnár Edina}

PhD föiskolai tanár

DE GTK Vezetés- és Szervezéstudományi Intézet, Szolnok molnar.edina.phd@econ.unideb.hu 